\title{
野球による上腕骨小頭離断性骨軟骨炎に 対する外顆楔状骨切り術（吉津法）の経験
}

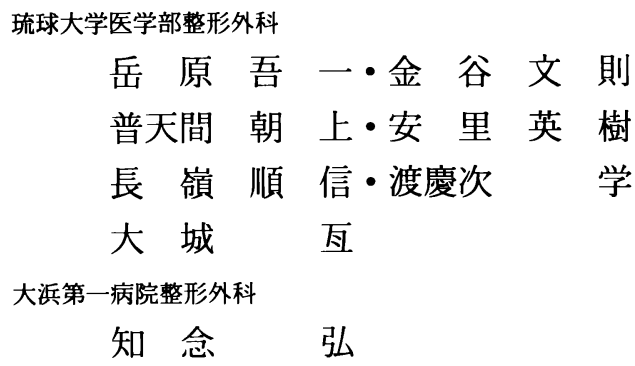

\section{Lateral Closing Wedge Osteotomy of Humerus for Osteochondritis Dissecans of the Capitellum}

\author{
Goichi Okahara, Fuminori Kanaya, Chojo Futenma, Hideki Asato, \\ Jyunshin Nagamine, Manabu Tokeshi, and Wataru Ohsiro \\ Department of Orthopedic Surgery, University of the Ryukyus \\ Hiroshi Chinen \\ Department of Orthopedic Surgery, Ohama Daiichi Hospital
}

\begin{abstract}
Osteochondritis dissecans of the humeral capitellum is not uncommon in boys who have played baseball rigorously from a very young age. We report the surgical results of the lateral closing wedge osteotomy of the humerus first reported by Yoshizu. All 9 boys complained of elbow pain on throwing and batting, tenderness on lateral humeral condyle, and limited elbow motion. They needed to stop playing baseball or reduce their activity because of the pain. Separated (7) or freed (2) fragments from the capitellum were seen by radiogram in all boys. These boys were observed under conservative treatment for at least one month. The age at surgery ranged from 13 to 16 (mean; 14.8) years old. An osteotomy was performed to remove laterally based wedge bones which had a peak located at the junction between the capitellum and trochlea, and a peak angle was 10 degrees. In 7 of 9 boys, cancellous bones were grafted, and in 5 of the 9 boys, bone pegs were inserted to fix the fragments. The follow-up ranged from 9 to 105 months (mean 38 months). After the surgery, the pain was reduced or disappeared in all boys. The mean range of motion of the elbow joint did not change significantly after the surgery. Six to 8 months after the surgery, eight of the boys could play baseball as well as they could before developing the problem.
\end{abstract}

Key words : Osteochondritis dissecans (離断性骨軟骨炎), Capitellum (小頭), Osteotomy（骨切り） Baseball player (野球選手)

はじめに

近年少年野球の降盛に伴い, 野球が小学校低学年か
ら競技レベルで行われるようになってきている．その 結果起こる少年期スポーツ障害の一つに, 上腕骨小頭 離断性骨軟骨炎がある，今回われわれは吉津 ${ }^{12}$ により 
表 症例の概要

\begin{tabular}{|c|c|c|c|c|c|c|c|c|}
\hline 症例 & 年齢（歳） & 野球歴（年） & ポジション & 分類 & 術前可動域（ㅇ） & 術後可動域（º $)$ & 術後期間（月） & 運動時痛 \\
\hline 1 & 15 & 8 & 内野 & 遊離型 & $-10 / 120$ & $0 / 130$ & 9 & 消失 \\
\hline 2 & 13 & 5 & 内野 & 分離型 & $0 / 130$ & $4 / 120$ & 60 & 消失 \\
\hline 3 & 15 & 8 & 投手 & 分離型 & $-20 / 140$ & $-27 / 125$ & 48 & 軽減 \\
\hline 4 & 15 & 7 & 投手 & 分離型 & $-25 / 110$ & $0 / 125$ & 21 & 軽㙎 \\
\hline 5 & 16 & 7 & 投手 & 分離型 & $7 / 137$ & $-5 / 137$ & 59 & 消失 \\
\hline 6 & 14 & 4 & 投手 & 遊離型 & $-7 / 130$ & $-10 / 135$ & 16 & 消失 \\
\hline 7 & 16 & 5 & 内野 & 分離型 & $-10 / 140$ & $0 / 140$ & 12 & 消失 \\
\hline 8 & 15 & 8 & 内野 & 分離型 & $-33 / 140$ & $-34 / 130$ & 105 & 軽減 \\
\hline 9 & 14 & 6 & 投手 & 分離型 & $0 / 130$ & $6 / 126$ & 12 & 消失 \\
\hline 平均 & 14.8 & 7.4 & & & $-9.3 / 130.8$ & $-7.3 / 129.0$ & 38 & \\
\hline
\end{tabular}
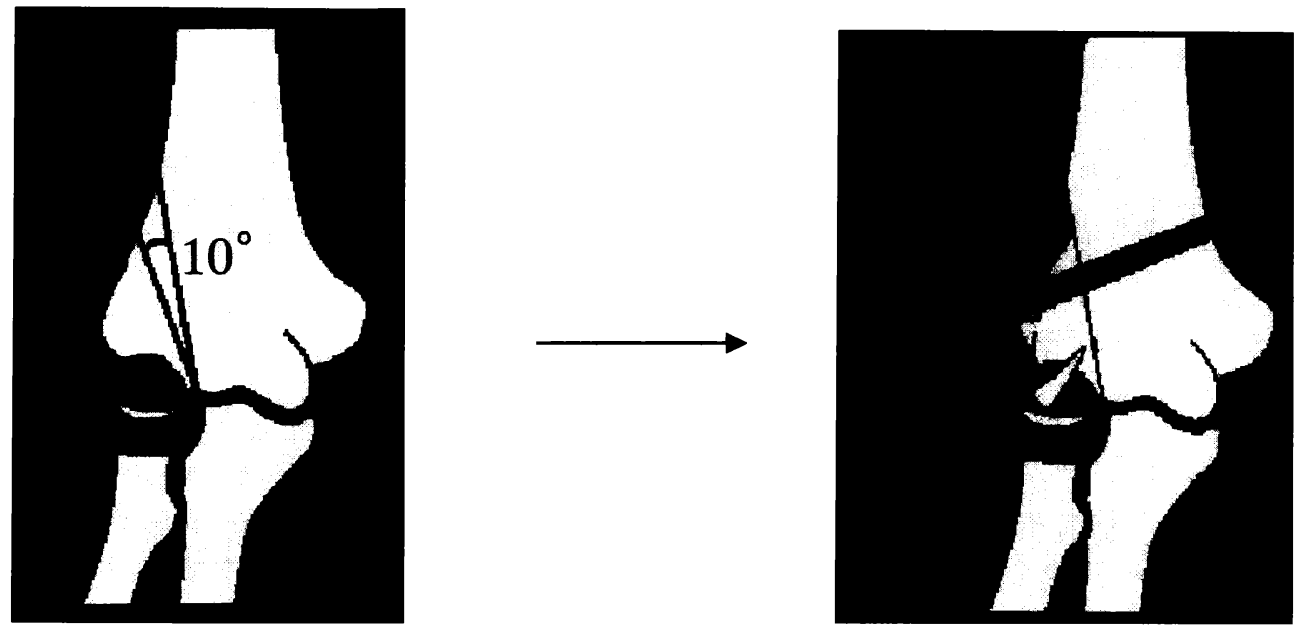

図 1 上腕骨外顆楔状骨切り術 吉津法に準じたが, 橈側側副勒帯は $Z$ 延長を行った. 軟骨に異常可動性のある場合は切除した骨片を利用し海綿骨を移植し, 骨釘で固定した.

報告された上腕骨外顆䝟状骨切り術を 9 例に行い, そ の術後成績について調査したので報告する.

\section{症 例 の 概 要}

症例は 9 例, 全例男子であり罹患側は右 4 例, 左 5 例であった．全員少年野球経験者でポジションは投手 5 例, 野手 4 例でうち 3 例は元投手であった。野球歴 は 4 年 8 年 (平均 7 年 5 力月), 时痛出現から初診 までの期間は 1 力月〜 5 年 (平均 1 年 2 力月), 初診 から手術までの期間は 1 力月〜 2 年 8 力月（平均 9.2 力月), 手術時年齢は $13 \sim 16$ 歳 (平均 14.8 歳) であっ た. 全例に投球，バッティング，腕立てふせなどの運 動時痛および外顆部の圧痛を認め, 平均 9 力月の保存 療法で症状改善のみられなかった例に手術を行った。

$\mathrm{X}$ 線所見は, 三浪の分類 ${ }^{6)}$ による分離型 7 例，遊
離型 2 例であった，術前肘関節平均可動域は伸展 $-9.3^{\circ}$, 屈曲 $130.8^{\circ}$ で, 術後経過観察期間は 9 力月か ら 8 年 9 力月 (平均 3 年 2 力月) であった (表).

\section{手 術 方 法}

手術は吉津の方法 ${ }^{1213)}$ に準じて施行した。 外側進入 で上腕骨小頭の血行を温存するため前面のみ軟部組織 を剥離し，橈側側副勒帯を切離後，小頭に約 $10^{\circ}$ の楔 状骨切りを行った，骨切り部を閉鎖し，皮質骨螺子を 用いて固定した。橈側側副勒帯はZ延長を行い修復し た (原法は切離). 軟骨に異常可動性のある場合は病 巣部の線維組織を择爬し, 海綿骨移植を行い, 骨切り 時に切除した骨片にて作製した骨釘を軟骨部から打ち 込み固定した（図1）。 


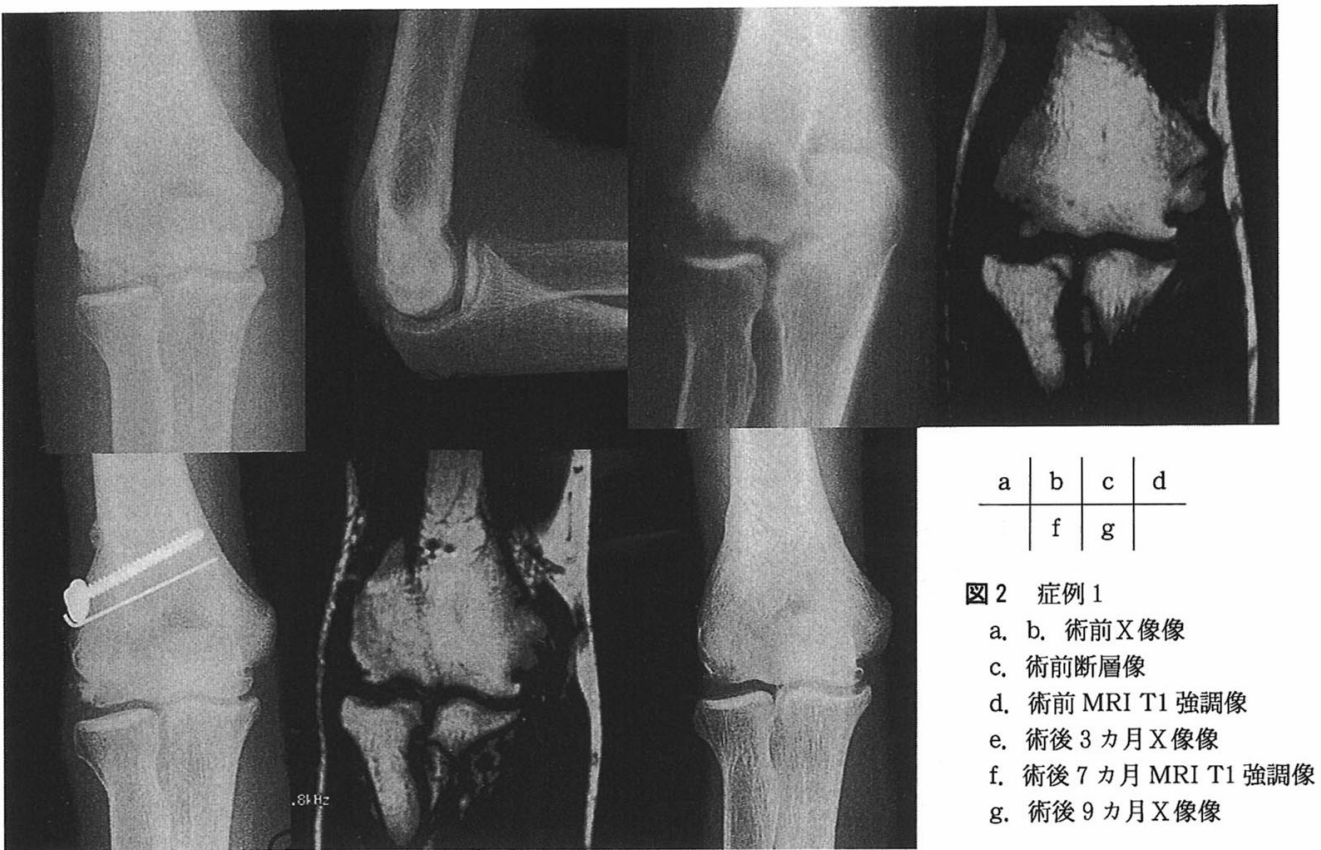

\section{術 後 療 法}

时関節 $90^{\circ}$ 屈曲, 前腕中間位でギプス固定を行い, 術後 3 〜 週間でギプスを除去し可動域訓練を開始し た. 術後 $3 \sim 4$ 力月で軽い投球練習を開始し, 術後 6 力月以降に全力投球を許可した.

結果

運動時痛は術後全例で軽減または消失した。術後平 均时関節可動域は伸展 $-7.3^{\circ}$, 屈曲 $129.0^{\circ}$ であった。 術後野球へ復帰したのは 9 例中 8 例で，復帰率 $88.9 \%$ であった。 8 例は全員手術前のポシシションに復帰して おり，復帰しなかった 1 例は中学卒業を機に退部した 症例であった，本格的な練習や試合に復帰するまでの 期間は 6 から 8 力月（平均 6.6 力月）であった（表）.

\section{症例}

代表症例を供覧する。

症例 $1: 15$ 歳 男子.

7 歳から野球を始め, 以後ポジションはサードであっ た. 毎日 $2 \sim 3$ 時間の練習を続け，13 歳頃から投球 時右肘痛が出現するようになった。 $2 \sim 3$ 力月投球を 控えると肘痛は軽快し投球を再開することができた。
14 歳頃から物を持つなど日常生活動作でも疼痛を きたすようになったため当科を受彰した，右上腕骨外 顆部に軽度の腫脹と圧痛を認め, 術前肘関節可動域は 伸展 $-10^{\circ}$ ，屈曲 $120^{\circ}$ と可動域制限を認めた．X線所 見では遊離型で健側に比べて橈骨頭の肥大化および早 期骨端線閉鎖もみられた（図 $2-a, b)$ ）断層撮影像 にて病巣部に骨透亮像を認め, 術前 MRI T1 強調像 にて，小頭の軟骨下骨に低信号域を認めた（図 $2-c$, d). 遊離体摘出後外顆に 10 度の楔状骨切りを加え, 病巣部の掻爬・海綿骨移植の後, 骨釘を打ち込んだ. 術後 3 力月で小頭の修復を認め, 軽い投球練習を開始 した。術後 7 力月の MRI で上腕骨小頭はよく修復さ れており, 全力投球でも疼痛を認めなかった. 術後 9 カ月で小頭はほぼ修復されており（図 $2-\mathrm{e}, \mathrm{f}, \mathrm{g}$ ), 时可動域は伸展 $0^{\circ}$, 屈曲 $130^{\circ}$ と改善している。

症例 $2: 13$ 歳男子.

小学校 3 年から投手, 内野手として週 5 日の練習を 続け, 12 歳頃から右肘痛が出現するようになった。 X線所見は分離型で, 術前肘可動域は伸展 $0^{\circ}$, 屈曲 $130^{\circ}$ であった。 上腕骨外顆に 10 度の楔状骨切りを加 え, 病巣部の搔爬・海綿骨移值の後, 骨釘を打ち込ん だ.

術後 6 力月で野球に復版したが，4 年後右肘ロッキ 


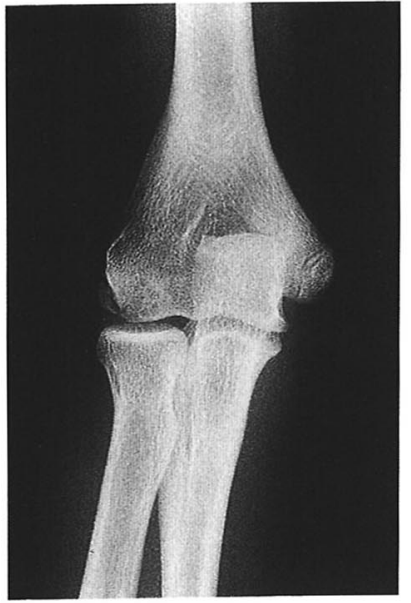

a

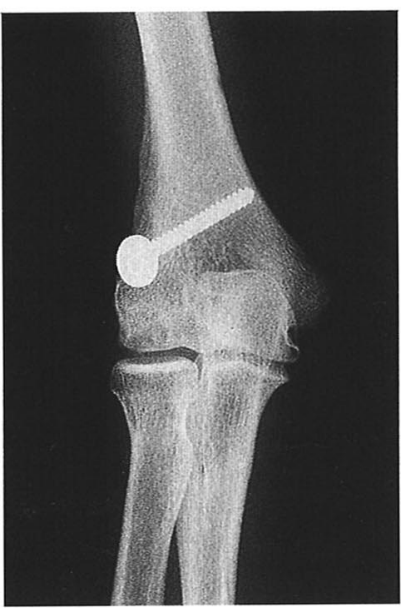

b

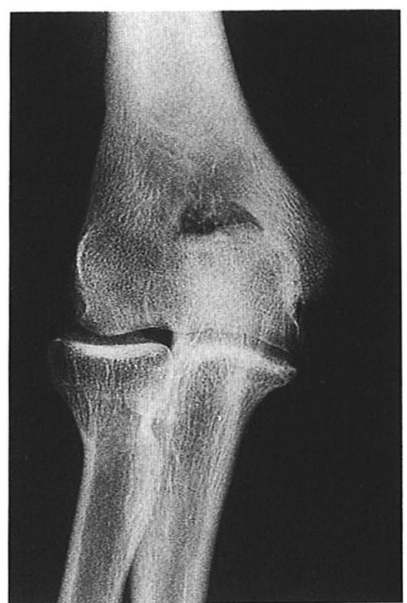

c

図 3 症例 2

a. 術前 $\mathrm{X}$ 像像 : 分離型.

b. 術後 3 力月 X像像: 骨切り部は骨癋合し, 小頭の修復を認める.

c. 術後 5 年X像像 : 橈骨頭の肥大化を認める.

ングを主訴に来院し遊離体摘出術を行った，骨切り術 後 5 年の現在X線にて橈骨頭は肥大化し, 肘可動域は 伸展 $4^{\circ}$, 屈曲 $120^{\circ}$ 之屈曲角の低下を認めるが, 投球 時痛むなく高校野球の外野レギュラーとして活躍して いる(図 $3-a, b, c)$.

$$
\text { 考察 }
$$

少年野球選手の検診調查によると柏口らは $44.5 \%$ に 时疼痛の既往があり，X線検查にて 19.5\%に骨軟骨障 害を認め, 上腕骨小頭障害の発生頻度は $1.6 \%$ である と報告している゙.

上腕骨小頭離断性骨軟骨炎では透亮型や分離型軽症 例に対してまず 6 力月以上の保存療法が行われるが, スポーツ禁止や患肢安静にて修復傾向を示さない例や， 分離型進行期, 遊離型に対しては手術療法が考慮され $3^{7)}$.

一方, 児童のほとんどは症状進行後に来院すること が多く, X線所見で異常が認められた場合は, 実際の 小頭部の変化は想像以上に進行しており手術療法を第 一選択とする意見もある ${ }^{13)}$. 岡村らはMRI にて病期 決定, 治療法選択を行っており, 軟骨下骨の連続性が 正常なら保存的に, 断裂を認めれば観血的に治療しそ れぞれ良好な結果であったと報告している8 ${ }^{8}$. 保存療
法による小頭修復について柏口らは，透亮型では修復 率 $90.4 \%$ であったのに対し，分離型では $52.9 \%$ であり 分離型における保存療法の効果は低いと報告してい る4).

現在我々は时の疼痛, 可動域制限を訴え, 早期運動 復㷌を希望する分離型・遊離型例に対して, 積極的に 観血的治療（外顆楔状骨切り術）を行っている. 外顆 楔状骨切り術はキーンベック病に対する前腕骨短縮術 にヒントを得た方法で, 吉津は圧迫力減少と骨切り効 果による上腕骨小頭の早期修復および腕橈関節形態の 維持が治療効果として期待できると述べている ${ }^{12)}$. 同 様な骨切り術を用いた場合の短期治療成績についても 比較的良好な結果が報告されている(1)910). 吉津は早 期復帰をめざす透亮型や，再発防止を目的とした遊離 型を含め，すべての症例に骨切りの適応があるとして いる ${ }^{13)}$ ．その他の術式としてドリリング2，骨釘移植 術 $^{2)}$, 时筋柄付き骨釘移植術 ${ }^{3}$, 骨軟骨片ワイヤ一固 定法 ${ }^{5)}$ な゙種々の方法が報告されており成績はそれぞ れ異なる。

本疾患は活動活発な学童に発症することああり, ス ポーツ禁止期間が出来るだけ短い治療法が理想であり, 今回の結果では 9 例中 8 例 $(88.9 \%)$ が平均 6.6 力月 で本格的練習レベルに復帰できている．外顆楔状骨切 
り術は他の方法と異なり，腕橈関節を減圧することか ら, 再発予防の観点加ら本疾患に理想的な治療法の 一つと考える.しかしそれ以前に指導者による適切な 練習量の設定などで障害を未然に防ぐこと，早期発見。 早期治療開始が重要なことは言うまでもない.

$$
\text { ま と め }
$$

1.上腕骨小頭離断性骨軟骨炎 9 例に対し外顆楔状 骨切り術を行い, 8 例が平均 6.6 力月で野球に復帰し た.

2. 同骨切り術は早期運動復帰をめざす分離型, 遊 離型例に対して有効な治療法であった。

\section{参文 献}

1）波多野光裕ほか：スポーツによる上腕骨小頭離断性骨 軟骨炎に対する外顆楔状骨切り術の経験. 整形外科, 43 ： 643-646, 1992.

2）藤田寛二，米田 實，塩野谷 香 : 野球が原因と考え られる上腕骨小頭の離断性骨軟骨炎の 10 例. 臨床スポー ッ医学, 7:689-691, 1990.

3）岩瀬毅信 : 肘関節離断性骨軟骨症の手術一时筋柄付骨 釘移植術を中心に一。臨・整・外., $22: 1296-1302$
1987.

4）柏口新二, 井形高明 : 上腕骨小頭障害の保存療法, MB Orthop., $10: 67-74,1997$.

5）近藤 稔, 麻生邦一：野球による时離断性骨軟骨炎の 手術療法. 整・災外., 32：1451-1459，1989.

6）三浪三干男ほか：时関節に発生した離断性骨軟骨炎の 25 例の検討. 臨整外., $14: 805-810,1979$.

7）岡 義範：野球肘. MB Orthop., $9: 183-191,1996$

8）岡村良久, 原田征行 : 上腕骨小頭離断性骨軟骨炎の画 像診断。臨床スポーツ医学, $12: 645-651 ， 1995$.

9）瀬木治郎ほか：上腕骨小頭揳状骨切り術（吉津法）に よる野球肘の治療経験. 中部整災誌., $32: 401-404$, 1990.

10）营沼悦子ほか：野球による肘離断性骨軟骨炎に対する 外顆揳状骨切り術の治療経験. 整形外科., 44: 488-492, 1993.

11) TAKAHARA, M. et al. : Early Detection of Osteochondritis Dissecans of the Capitellum in Young Baseball Players. J. Bone and Joint Surg., 80 - A, 892 897, 1998.

12）吉津孝衛：野球肘に伴う上腕骨小頭離断性骨軟骨炎へ の新治療法一外顆揳状骨切り術について一. 整形外科, $37: 1232-1242,1986$.

13）吉津孝衛 : 離断性骨軟骨炎の観血的治療. MB Orthop., $10: 83-95,1997$. 